\title{
Penyuluhan Literasi Belajar Online untuk Masyarakat Bersama Komunitas Pemuda Mandiri
}

\author{
Didin Hadi Saputra ${ }^{*}$, Muhammad Shohibul Ihsan², Lalu Gede Muhammad Zainuddin \\ Atsani $^{3}$ iD \\ ${ }^{1}$ Program Studi Adiministrasi Publik, Universitas Nahdlatul Wathan Mataram, Indonesia \\ ${ }^{2}$ Program Studi Biologi, Universitas Nahdlatul Wathan Mataram, Indonesia \\ ${ }^{3}$ Program Studi Pendidikan Agama Islam, Institut Agama Islam Hamzanwadi Nahdlatul Wathan Lombok Timur, Indonesia \\ *Corresponding author: saputra7889@gmail.com
}

\begin{abstract}
Abstrak
Pandemi covid-19 mengharuskan setiap pelaksanaan proses pembelajaran dilakukan secara online, sehingga setiap komponen pendidikan dituntut untuk memiliki litersi belajar online yang baik. Kegiatan pengabdian masyarakat ini bertujuan untuk memberikan pelatihan dan pendampingan tentang literasi pembelajaran online kepada masyarakat secara umum, serta mendampingi masyarakat dengan intensif dan berkelanjutan bagaimana menggunakan media belajar dengan bijak agar belajar lebih efektif dan bermanfaat. Metode yang digunakan dalam kegiatan pengabdian ini adalah tahap observasi, tahap penyusunan program, tahap sosialisasi dan tahap evaluasi. Dalam kegiatan ini diperoleh output atau luaran yakni sebagian besar peserta yang mengikuti pelatihan ini sangat komunikatif serta memberikan gambaran kepada tim pengabdi bahwa semangat peserta dalam mengikuti pengabdian sangat tinggi. Hal ini terbukti dengan aktifnya mitra pengabdian (komunitas pemuda) dalam membantu tim pengabdi dalam membimbing masyarakat melakukan literasi pembelajaran dengan tatap muka dan membimbing langsung pembelajar tersbeut melalui media yang telah disediakan (LCD proyektor).
\end{abstract}

Kata Kunci: Penyuluhan, Literasi Belajar Online

\section{Abstract}

The COVID-19 pandemic requires that every implementation of the learning process be carried out online, so that every component of education is required to have good online learning literacy. This community service activity aims to provide training and assistance on online learning literacy to the public in general, as well as intensively and sustainably assist the community on how to use learning media wisely so that learning is more effective and useful. The method used in this service activity is the observation stage, the program preparation stage, the socialization stage and the evaluation stage. In this activity, the output or output was obtained, namely most of the participants who took part in this training were very communicative and gave an illustration to the service team that the enthusiasm of the participants in participating in the service was very high. This is evidenced by the active participation of community service partners (youth communities) in assisting the service team in guiding the community to carry out learning literacy face-to-face and directly guiding the learners through the media provided (LCD projector.

\section{Keywords: Counseling, Literacy Online Learning}

\section{INTRODUCTION}

Adanya pandemi virus covid-19 yang melanda seluruh wilayah Indonesia memberikan dampak yang sangat signifikan terhadap tatanan kehidupan masyarakat di segala bidang, termasuk dalam bidang pendidikan (Astini, 2020). Pandemi virus covid-19 mengakibatkan seluruh proses pendidikan dilakukan secara online atau daring. Pembelajaran online/daring merupakan suatu proses pembelajaran yang dilaksanakan dengan memanfaatkan jaringan internet dan berbagai platform pembelajaran seperti google classroom, zoom, google meet, dll (Dewi, 2020; Yunitasari \& Hanifah, 2020). Pembelajaran online menjadi salah satu solusi terbaik yang dapat digunakan untuk menekan penyebaran

$\begin{array}{ll}\text { History: } & \\ \text { Received } & \text { : April 10, } 2021 \\ \text { Revised } & \text { : April 12, } 2021 \\ \text { Accepted } & \text { : May 20, } 2021 \\ \text { Published } & \text { : May 25, } 2021\end{array}$


virus covid-19 di lingkungan sekolah. Hal ini dikarenakan melalui proses pembelajaran secara online siswa dan guru dapat mengikuti kegiatan pembelajaran dimana saja dan kapan saja tanpa harus bertemu secara langsung (Rigianti, 2020). Terdapat berbagai macam manfaat yang dapat dirasakan saat pelaksanaan pembelajaran online seperti: 1) menciptakan komunikasi yang efektif dan efesien antara guru dengan orang tua siswa, 2) mempermudah proses interaksi antara guru, siswa, dan orang tua, mempermudah guru dalam proses pemberian materi pembelajaran, 3) guru dapat dengan mudah menyusun soal, tanpa terkendala waktu dan tempat, serta 4) dapat meningkatkan kemampuan literasi digital guru dan siswa (Nugraha et al., 2020; Sobron et al., 2019).

Kemampuan literasi digital diartikan sebagai kemampuan penguasaan teknologi, seperti teknologi dalam pendidikan (Amilia, 2019). Pada proses pembelajaran daring guru dan siswa dituntut untuk memiliki literasi digital yang baik untuk memenuhi tujuan pembelajaran (Pohan \& Suparman, 2020). Namun pada kenyataannya dilapangan kemampaun literasi digital guru dan siswa selamam proses pembelajaran online maish tergolong rendah, sehingga menimbulkan rasa tidak nyaman pada saat proses belajar serta turunya kualitas belajar (Harahap et al., 2021; Oyedotun, 2020). Lemahnya literasi digital pada saat pembelajaran online lebih banyak dialami oleh siswa/masyarakat yang berada di daerah pedesaan (Widikasih et al., 2021). Hal ini sejalan dengan hasil observasi yang telah dilakukan di Desa Sapit Kecamatan Suela, Lombok Timur.

Desa Sapit Kecamatan Suela, Lombok Timur terletak di salah satu lereng bukit menuju Gunung Rinjani Propinsi Nusa Tenggra Barat. Desa Sapit merupakan desa yang memiliki suhu yang dingin, karena terletak di lereng bukit menuju arah Gunung Rinjani. Kondisi desa yang dapat dikatakan berada di daerah pedalam mengakibatkan akses masyarakat untuk belajar online sangat terbatas, dikarenakan akses signal yang masih rendah, sebagian juga masyarakat masih terbatas dalam menggunakan HP atau ponsel sebagai alat utama dalam mengakses media informasi, serta masih terbatasnya pemahaman warga masyarakat terhadap media yang digunakan dalam belajar online. Salah satu upaya yang dapat dilakukan untuk mengatasi masalah mengenai rendahnya kemampuan literasi belajar online masyarakat Desa Sampit, yakni dengan memberikan penyuluhan mengenai literasi belajar online. Kegiatan penyuluan merupakan suatu bentuk pengabdian masyarakat yang dilakukan untuk meningkatkan kualitas sumber daya manusia di suatu daerah (Badrianto \& Ekhsan, 2020). Penyuluhan yang dilakukan di Desa Sampit, difokuskan pada kelompok muda mudi, yang dianggap mampu menerima materi dengan baik dan mampu menyalurkan ilmunya kepada pihak yang lebih tua atau lebih muda. Selain itu muda-mudi di daerah Desa Sampit memiliki semangat belajar yang sangat tinggi, serta sifat keingin tahuan mereka tentag belajar online juga tinggi. Sehingga mereka tidak lagi menganggap bahwa pembelajaran itu hanya dilakukan di sekolah atau ditempat formal, namun bias dimanapun juga boleh, selama ditempat tertentu ada signal atau ada perangkat pendukung dalam belajar online.

Salah satu faktor yang membuat kegiatan pengabdian ini penting dan layak untuk dikaji, yakni kondisi geografis atau lokasi pengabdian yang cenderung bergunung dan signal ponsel dari beberapa operator yang terkadang muncul, dan juga terkadang hilang. Factor ini juga sebagai salah satu ajang "trial and eror" terhadap signal di HP yang digunakan oleh peserta pengabdian. Bila salah satu signal operator yang digunakan oleh peserta pengabdian berada pada level "sangat baik", maka singal operator tersebutlah yang akan digunakan, namun bila signal HP kurang maksimal atau bahkan tidak ada, maka akan digantikan dengan alternative yang lain. Adapun tujuan dari pelaksanaan kegiatan ini yakni untuk memberikan pelatihan dan pendampingan tentang literasi pembelajaran online kepada masyarakat secara 
umum, serta mendampingi masyarakat dengan intensif dan berkelanjutan bagaimana menggunakan media belajar dengan bijak agar belajar lebih efektif dan bermanfaat.

\section{MATERIALS AND METHODS}

Kegiatan pengabdian ini dilaksanakan di Desa Sampit, Kecamatan Suela, Lombok timur, dan dilaksanakan dalam 3 tahap pelaksanaan. Tahap pertama yakni tahap obsevasi yang dilakukan dengan melaksanakan kunjungan awal tim pengabdi bersama mitra pengabdian, yakni komunitas pemuda. Kegiatan awal ini dilaksanakan untuk mengkaji persoalan atau masalah awal yang ada di lokasi pengabdian, tahap observasi iniah yang akan dijadikan dasar dalam penentuan jenis kegiatan pengabdian yang diadakan di desa Sapit Kecamatan Suela. Tahap kedua adalah tahap menyusun program kegiatan yang telah dipetakan bersama tim pengabdi sebelum melakukan observasi. Yang dilakukan ditahap kedua ini adalah menyusun jadwal dan jenis kegiatan yang akan dilaksanakan, seperti dimana lokasi kegiatan pengabdian dilakukan, siapa peserta dan pemateri (tambahan) nya, berapa jumlah mitra yang terlibat, waktu (tanggal dan waktu) pelaksanaan, atribut yang akan dibawa, serta berapa lama waktu kegiatan pengabdian akan dilaksanakan atau akan berlangsung.

Selanjutnya, yakni tahap ketiga, yakni persiapan sosialisasi serta materi yang akan disampaikan, tahap ini merupakan tahap inti dari kegiatan pengabdian. Ditahap ketiga ini merupakan tahap yang mempunyai proses cukup panjang, artinya, ditahap ini segala macam narasi atau rentetan kegiatan pengabdian akan di uraikan, mulai dari teknik penyampaian materi, kesulitaan yang dihadapi selama melaksanakan kegiatan pengabdian, apa dampak atau hasil yang akan diberikan dari kegiatan pengabdian yang dilaksanakan, bagamana antusiasme atau tanggapan dari peserta pengabdian atau mitra pengabdian, serta bagaimana tindak lanjut dari pelaksanaan pengabdian setelah kegiatan pengabdian ini terlaksana sesuai jadwal, dan lain lain, dan tahap keempat, yakni tahap pelaporan, tahap dimana seluruh kegiatan pengabdian kepada masyarakatakan di laporkan kepada pihak LPPM sebagai lembaga yang menaungi seluruh kegiatan penelitian dan pengabdian. Tahap keempat merupakan kegiatan evaluasi seluruh rangkaian acara.

\section{RESULTS AND DISCUSSION}

Luaran atau hasil dari pengabdian yang lakukan yakni berupa kegiatan yang dilaksanakan dengan standar kesehatan Covid-19. Kegiatan literasi online kepada masyarakat yang dilakukan bersama komunitas pemuda Desa Sapit merupakan langkah awal yang dilakukan oleh tim pengabdi dari Universitas Nahdlatul Wathan Mataram dan Institute Agama Islam Hamzanwadi Lombok Timur, yang berasal dari berbagai macam Fakultas, Fakultas MIPA, Fakultas Ilmu Administrasi dan Fakultas Agama Islam. Kegiatan pengabdian dosen dalam bentuk literasi kepada masyarakat haruslah terlaksana dengan utuh dan komprehensif. Kegiatan ini berbentuk diskusi mini bersama pendampingan dari mitra (Mujahidin \& Arinda, 2021). Diskusi yang diselenggarakan telah melibatkan para kaum muda yang ingin praktik langsung tentang belajar secara online dengan materi pengabdian yang telah disiapkan sebelumnya. Diskusi berlangsung selama dua kali atau dua gelombang, yakni gelombang pertama dari jam 09.00 pagi hingga jam 10.00 pagi, serta gelombang kedua jam 11.00 siang hingga jam 13.00 siang. Kegiatan pengabdian dioptimalkan dengan penggunaan HP gadget dari para mitra pengabdian, yakni komunitas pemuda desa Sapit dalam mensosialisasikan literasi belajar online.

Adapun hasil dari pelaksanaan program ditinjau darai setiap proses pelaksanaan adalah: pada tahap pertama yakni tahap observasi, didapatkan informasi bahwa masyarakat Desa Sampit, Kecamatan Suela, Lombok timur memiliki kemampuan literasi belajar online 
yang masih rendah. Hal ini disebabkan karena kondisi geografis desa yang cenderung berada di daerah pedalaman, sehingga kualitas sinyal serta jaringan internet di Desa tersebut dapat dikatakan buruk sehingga tidak memungkinkan untuk melaksanakan pembelajaran online secara maksimal. Hasil penelitian ini sejalan dengan hasil penelitian yang telah dilakukan oleh (Widikasih et al., 2021) yang menyatakan bahwa 50,5\% masyarakat daerah desa memiliki kemampuan literasi digital yang rendah. Rendahnya kemampuan literasi belajar online ini disebabkan karna masyarakat kurang terbiasa dengan penggunaan teknologi, serta kondisi wilayah yang tidak memungkinkan adanya akses internet yang baik (Sulistyowati et al., 2021).

Tahap pelaksanaan kedua, yakni tahap penyusunan program dan penyusunan jadwal kegiatan. Berdasarkan hasil diskusi bersama tim pelaksana dan mitra maka ditentukan program yang akan dijalankan yakni "penyuluhan literasi belajar online". Program penyuluhan literasi belajar online ini dipilih mengingat adanya fenomena pandemic covid-19 yang mengaharuskan setiap proses pembelajaran dilakukan secara online/daring. Banyaknya kendala yang dialami oleh siswa maupun masyarakat dalam pelaksanaan pembelajaran daring menjadi salah satu penyebab belum maksimalnya proses pembelajaran dilakukan (Roni \& Asep Priatna, 2020). Sehingga dengan adanya program ini diharapkan dapat meningkatkan kemampuan literasi belajar online masyarakat kususnya remaja yang masih mengeyam pendidikan. Literasi belajar online pada dasarnya merupakan kemampuan yang dimiliki seseorang untuk menggunakan teknologi pembelajaran daring (Nahdi et al., 2020). Di masa pandemic covid-19 ini kemampuan penggunaan teknologi sangatlah dibutuhkan untuk menunjang proses belajar. Penguasaan teknologi oleh guru dan siswa menjadi salah satu indikator susksesnya proses pembelajaran daring. Pembelajaran daring sendiri merupakan suatu proses pembelajaran yang dilakukan dengan memanfaatkan berbai platform digital seperti zoom, google meet, google classroom, dll (Gunawan et al., 2020; Rigianti, 2020). Bagi masyarakat desa yang tidak terbiasanya dengan penggunaan teknologi proses pembelajaran daring tentu menjadi masalah besar yang membutuhkan perhatian kusus, sehingga program penyulahn ini dapat menjadi salah satu solusi yang tepat.

Selain penyuluhan literasi belajar online untuk menunjang pembelajaran daring, kegiatan ini juga dilaksanakan untuk meningkatkan kemampuan penggunaan teknologi masyarakat, mengingat Desa Sampit merupakan desa wisata yang banyak dikunjungi oleh wisawatwan setip tahunnya, dimana melalui program ini masyarakat juga dapat belajar mengenai melaksanakan promosi desa wisata dan mengembangkan kemajuan desanya. Tahap pelaksanaan ketiga, yakni persiapan dan pelaksanaan sosialisasi. Kegiatan dilaksanakan dalam 2 gelombang yakni gelombang pertama dari jam 09.00 pagi hingga jam 10.00 pagi, serta gelombang kedua jam 11.00 siang hingga jam 13.00 siang, dimana kegiatan difokuskan terhadap peningkatan kemampuan masyarakat dalam melaksanakan proses belajar online. Hasil yang ditunjukkan dalam pelaksanaan kegiatan ini yakni kegiatan literasi belajar online dengan masyarakat desa Sapit berlangsung lancar dengan menggunakan standar protokol ketat Covid-19. Antusisme warga masyarakat yang didampingi oleh pemuda Desa Sapit sangat mendukung kegiatan ini terus berlangsung hingga akhir.

Dalam kegiatan ini diperoleh output atau luaran yakni sebagian besar peserta yang mengikuti pelatihan ini sangat komunikatif serta memberikan gambaran kepada tim pengabdi bahwa semangat peserta dalam mengikuti pengabdian sangat tinggi. Hal ini terbukti dengan aktifnya mitra pengabdian (komunitas pemuda) dalam membantu tim pengabdi dalam membimbing masyarakat melakukan literasi pembelajaran dengan tatap muka dan membimbing langsung pembelajar tersbeut melalui media yang telah disediakan (LCD proyektor). Salah satu upaya tim pengabdi dalam membantu memberikan uraian atau bagaimana menjelaskan kepada peserta pengabdian yakni membantu mereka bagaimana 
membaca online atau belajar online yan bermanfaat untuk membuka cakrawala informasi dunia. Peserta yang mengikuti kegiatan pengabdian masyarakat berharap agar kegiatan ini bisa berlanjut dan diteruskan di lain waktu dan dengan tema dan kegiatan yang berbeda pula

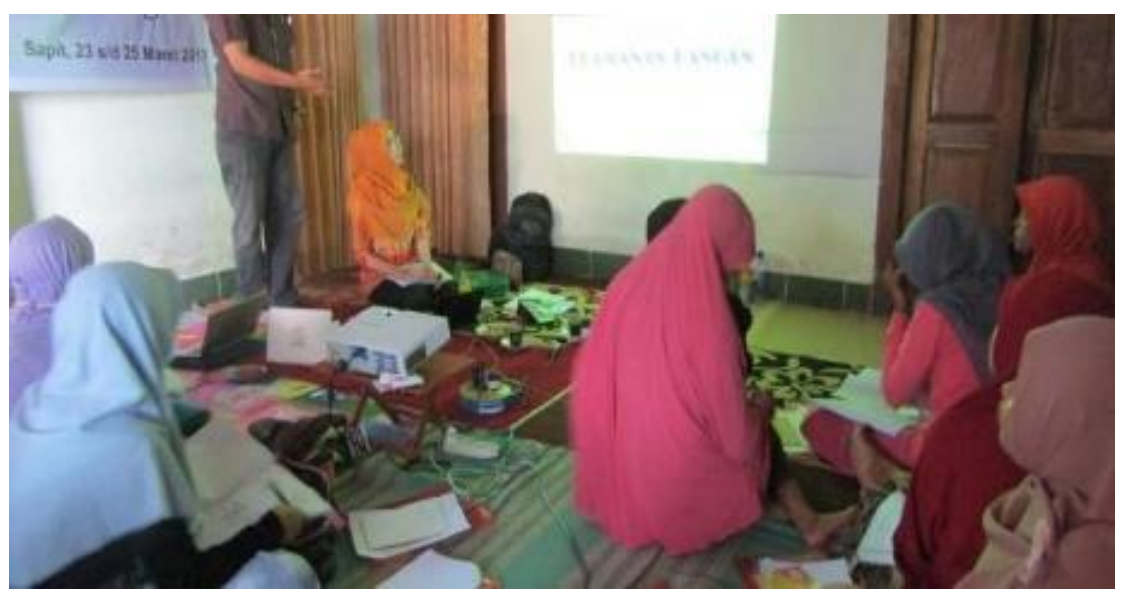

Gambar 1. Suasana pelaksanaan pengabdian

\section{CONCLUSION}

Kegiatan pengabdian di Desa Sampit, Kecamatan Suela, Lombok timur dilaksanaan dengan memberikan penyuluhan mengenai literasi belajar online yang ditujukan kepada masyarakat dan muda mudi di Desa tersebut. Kegiatan penyuluhan dilaksanakan dalam 3 tahap yakni tahap obsevasi, tahap menyusun program, serta tahap persiapan sosialisasi serta materi yang akan disampaikan. Hasil dari pelaksanaan program ini menunjukkan bahwa masyarakat serta muda mudi sangat antusias dalam mengikuti program pelatihan serta mendukung penuh pelaksanaan program, sehingga program dapat terlaksana dengan baik dan mampu meningkatkan kemampuan literasi beljar online masyarakat.

\section{REFERENCES}

Amilia, F. (2019). Kompetensi Literasi Infomasi Guru Paud Di Era 4.0: Antara Tuntutan Dan Realitas. Jurnal Pengabdian Masyarakat Ipteks, 5(2), 124-129. https://doi.org/https://doi.org/10.32528/jpmi.v5i2.2936.

Astini, N. K. S. (2020). Pemanfaatan Teknologi Informasi dalam Pembelajaran Tingkat Sekolah Dasar pada Masa Pandemi Covid-19. JURNAL LAMPUHYANG, 11(2). https://doi.org/https://doi.org/10.47730/jurnallampuhyang.v11i2.194.

Badrianto, Y., \& Ekhsan, M. (2020). Strategi Pengembangan Sumber Daya Manusia Melalui Pemberdayaan Dan Peningkatan Kualitas Lingkungan Desa Cikedokan. Jurnal Pengabdian Kepada Masyarakat, 1(1), 168-175. http://www.openjournal. unpam.ac.id/index.php/kommas/article/view/4501.

Dewi, W. A. F. (2020). Dampak Covid-19 Terhadap Implementasi Pembelajaran Daring Di Sekolah Dasar. Jurnal Ilmu Pendidikan, 2(1), 55-61. https://doi.org/10.31004 /edukatif.v2i1.89.

Gunawan, Suranti, N. M. Y., \& Fathoroni. (2020). Variations of Models and Learning Platforms for Prospective Teachers During the COVID-19 Pandemic Period. Indonesian Journal of Teacher Education, 1(2), 61-70. https://journal.publicationcenter.com/index.php/ijte/article/view/95/48.

Harahap, S. A., Dimyati, D., \& Purwanta, E. (2021). Problematika Pembelajaran Daring dan Luring Anak Usia Dini bagi Guru dan Orang tua di Masa Pandemi Covid 19. Jurnal 
Obsesi: Jurnal Pendidikan Anak Usia Dini, 5(2), 1825-1836. https://doi.org/10.31004/obsesi.v5i2.1013.

Mujahidin, I., \& Arinda, P. S. (2021). MATAPPA : Jurnal Pengabdian Kepada Masyarakat Workshop E-Learning Berbasis Web E-Class Untuk Meningkatkan Interaksi Pembelajaran Jarak Jauh. 4, 14-18.

Nahdi, K., Ramdhani, S., Yuliatin, R. R., \& Hadi, Y. A. (2020). Implementasi Pembelajaran pada Masa Lockdown bagi Lembaga PAUD di Kabupaten Lombok Timur. Jurnal Obsesi: Jurnal Pendidikan Anak Usia Dini, 5(1), 177. https://doi.org/10. 31004/obsesi.v5i1.529.

Nugraha, S. A., Sudiatmi, T., \& Suswandari, M. (2020). Studi Pengaruh Daring Learning Terhadap Hasil Belajar Matematika Kelas IV. Jurnal Inovasi Penelitian, 1(3), 265276. https://doi.org/https://doi.org/10.47492/jip.v1i3.74.

Oyedotun, T. D. (2020). Sudden change of pedagogy in education driven by COVID-19: Perspectives and evaluation from a developing country. Research in Globalization, 2(October), 100029. https://doi.org/10.1016/j.resglo.2020.100029.

Pohan, S. S., \& Suparman. (2020). Perspektif Literasi Digital Bagi Guru Sekolah Dasar. Jurnal Ilmu-Ilmu Sejarah, Sosial, Budaya Dan Kependidikan, 7(1), 164-178. https://doi.org/https://doi.org/10.33059/jsnbl.v7i2.2932.

Rigianti, H. A. (2020). Kendala Pembelajaran Daring Guru Sekolah Dasar Di Kabupaten Banjarnegara. 21(1), 1-9.

Roni, H. A., \& Asep Priatna. (2020). Efektifitas Implementasi Pembelajaran Daring (Full Online) Dimasa Pandemi Covid- 19 Pada Jenjang Sekolah Dasar Di Kabupaten Subang. Jurnal Ilmiah PGSD STKIP Subang, 6(1), 1-9. https://doi.org/ 10.36989/didaktik.v6i1.120.

Sobron, Bayu, Rani, \& S, M. (2019). Pengaruh Daring Learning terhadap Hasil Belajar IPA Siswa Sekolah Dasar. Prosiding Seminar Nasional Dan Enterpreneurship, 1-5. http://conference.upgris.ac.id/index.php/snse/article/view/204.

Sulistyowati, T., Sugiharto, M. A., \& Kumalasari, L. D. (2021). Pendampingan Pembelajaran Siswa Pada Era Pandemi Di Sekolah Dasar Muhammadiyah 1 Malang. Jurnal Pengabdian Kepada Masyarakat, 2(2), 569-576. https://doi.org/ 10.31949/jb.v2i2.812.

Widikasih, P. A., Widiana, I. W., \& Margunayasa, I. G. (2021). Online Learning Problems for Elementary School Students. Journal of Education Research and Evaluation, 5(3). https://doi.org/http://dx.doi.org/10.23887/jere.v5i3.34254.

Yunitasari, R., \& Hanifah, U. (2020). Pengaruh Pembelajaran Daring terhadap Minat Belajar Siswa pada Masa COVID-19. Edukatif: Jurnal Ilmu Pendidikan, 2(3), 232-243. https://doi.org/https://doi.org/10.31004/edukatif.v2i3.142. 